\title{
PENGEMBANGAN E-MODUL BERBANTUAN MEDIA CAI PADA MATA PELAJARAN FOTOGRAFI KELAS X DESAIN KOMUNIKASI VISUAL DI SMK NEGERI 1 SUKASADA
}

\author{
Komang Ariasa1), Gede Saindra Santyadiputra1), I Gede Partha Sindu1) \\ ${ }^{1}$ Fakultas Teknik dan Kejuruan, Universitas Pendidikan Ganesha \\ email: 1215051067@undiksha.ac.id, gsaindras@undiksha.ac.id, partha.sindu@undiksha.ac.id
}

\begin{abstract}
Abstrak
Tujuan penelitian ini (1) Untuk menghasilkan rancangan dan mengimplementasikan hasil rancangan pengembangan e-modul berbantuan media CAI pada mata pelajaran fotografi kelas $X$ Desain Komunikasi Visual di SMK Negeri 1 Sukasada, (2) Untuk mengetahui respon guru dan siswa terhadap pengembangan e-modul berbantuan media CAI pada mata pelajaran fotografi kelas X Desain Komunikasi Visual di SMK Negeri 1 Sukasada. Model pembelajaran yang diterapkan dalam pengembangan modul elektronik ini adalah model pembelajaran project based learning. Jenis penelitian yang digunakan dalam penelitian ini adalah penelitian dan pengembangan (Research and Development) dengan model pengembangan ADDIE. Subjek penelitian ini yaitu siswa kelas X Desain Komunikasi Visual di SMK Negeri 1 Sukasada tahun ajaran 2016/2017. Untuk mengetahui respon guru dan siswa terhadap e-modul fotografi diperoleh dengan menggunakan metode angket. Hasil penelitian menunjukkan bahwa: (1) Hasil rancangan dan implementasi e-modul berbantuan media CAl yang telah dikembangkan pada mata pelajaran fotografi kelas X Desain Komunikasi Visual di SMK Negeri 1 Sukasada dinyatakan berhasil diterapkan berdasarkan beberapa uji yang dilakukan. (2) Hasil analisis data respon guru menunjukkan bahwa, didapatkan rata-rata skor respon sebesar 47, jika dikonversikan ke dalam tabel penggolongan respon maka termasuk pada kategori sangat positif. Sedangkan untuk respon siswa terhadap pengembangan e-modul didapatkan rata-rata skor respon sebesar 67,79, jika dikonversikan ke dalam tabel penggolongan respon siswa termasuk pada kategori sangat positif.
\end{abstract}

\section{Kata kunci: E-Modul, Fotografi, Project Based Learning}

\begin{abstract}
The purposes of this study were (1) to generate a design and implement the result of the design for the development of e-modul assisted CAI media on the subject of photography for tenth grade of Desain Komunikasi Visual at SMK Negeri 1 Sukasada, (2) to know the responses of the teacher and students toward development of e-modul assisted CAI media on the subject of photography for tenth grade of Desain Komunikasi Visual at SMK Negeri 1 Sukasada. The learning model that used in the development of electronic modul was project based learning. The type of research used in this study was the Research and Development (R\&D) using ADDIE development model. The subjects of this study were tenth grade students of Desain Komunikasi Visual at SMK Negeri 1 Sukasada in academic year 2016/2017. In order to know the response of the teacher and students of e-module photography, questionnaire was used to obtain the data. The results showed that: (1) The design and implementation of e-module assisted CAI media which have been developed on the photography course for tenth grade of Desain Komunikasi Visual at SMK Negeri 1 Sukasada was successfully applied by some of the tests conducted. (2) The results of the data analysis showed that the mean score obtained from teacher's responses was 47 , if it converted into a table of classification response; it was classified as the category of very positive. Meanwhile, the mean score obtained from the students' response of the development of e-module, was 67,79 , if it converted into a table of classification response, student responses classified as category of very positive.
\end{abstract}




\section{Keywords: E-Module, Photography, Project Based Learning}

\section{PENDAHULUAN}

SMK Negeri 1 Sukasada merupakan salah satu sekolah menengah kejuruan Seni dan Teknologi di Bali Utara yang memiliki tanggung jawab dalam pengembangan bakat dan keahlian peserta didiknya. Saat ini SMK Negeri 1 Sukasada memiliki 9 Kompetensi Keahlian, salah satunya adalah jurusan Desain Komunikasi Visual. Salah satu mata pelajaran produktif yang terdapat pada jurusan Desain Komunikasi Visual yaitu fotografi, di mana pada mata pelajaran fotografi ini keahlian yang diberikan kepada para peserta didik adalah pemahaman dan keterampilan tentang mempersiapkan pemotretan fotografi, melaksanakan proses pemotretan fotografi, dan melaksanakan proses cetak foto.

Berdasarkan hasil observasi awal dan angket yang dilakukan dengan guru mata pelajaran fotografi di SMK Negeri 1 Sukasada, dapat diketahui bahwa ketersediaan sarana dan prasarana di laboratorium komputer sudah memadai. Namun kendala yang dialami guru pengajar yaitu 1) kurangnya sumber belajar berupa modul ajar/ buku khusus fotografi yang terstruktur dengan baik sebagai panduan dalam proses belajar mengajar di sekolah maupun di luar sekolah, 2) jumlah alat alat bantu fotografi yang terbatas karena harga relatif mahal sehingga tidak diketahui oleh siswa, 3) siswa hanya mengandalkan materi dari guru. Selain itu berdasarkan angket yang di sebar kepada 20 siswa kelas $X$ Desain Komunikasi Visual dari total jumlah 22 orang, dapat diketahui bahwa terdapat beberapa masalah yang dialami yaitu 1) siswa belum memiliki modul yang sesuai dengan standar kompetensi sehingga dalam proses pembelajaran hanya berpedoman pada penyampaian materi dari guru pengajar, 2) media pembelajaran yang digunakan selama ini belum membantu mengatasi masalah tidak adanya modul ajar, 3) siswa senang mencari materi di internet yang belum memiliki sumber jelas, 4) siswa lebih senang dengan pembelajaran media gambar, simulasi, dan video. Hal ini berdampak terhadap kurangnya tingkat pemahaman peserta didik dan pembelajaran cenderung berpusat pada guru, berbanding terbalik dengan penerapan kurikulum KTSP yang mengutamakan kegiatan pembelajaran berpusat pada siswa (student center).

Berdasarkan dari permasalahan tersebut, dibutuhkan suatu media ajar yang dapat menarik minat dan kemandirian siswa, memudahkan guru dalam menyampaikan materi selama proses belajar mengajar, dan media ajar yang mudah diakses dan dipelajari walaupun terbatas akan alat pendukung pembelajaran. Salah satu media pembelajaran yang dapat menjadi solusi atas permasalahan yang sedang dialami jurusan Desain Komunikasi Visual di SMK Negeri 1 Sukasada adalah modul pembelajaran interaktif berupa elektronik modul (e-modul) berbasis web yang dikemas dengan berbagai penyajian materi yang lebih konkret, nyata, dan dilengkapi simulasi pendukung pembelajaran sesuai dengan perkembangan teknologi terkini.

Modul elektronik merupakan pengembangan modul cetak dalam bentuk digital yang banyak mengadaptasi dari modul cetak. Pengembangan e-modul dapat dipadukan dengan model pembelajaran yang dipandang mampu meningkatkan hasil belajar siswa, pada penelitian ini model pembelajaran yang digunakan adalah project based learning. Pembelajaran berbasis proyek adalah suatu model pembelajaran yang melibatkan suatu proyek dalam proses pembelajaran. Dalam pembelajaran berbasis proyek siswa menjadi terdorong lebih aktif dalam belajar, guru hanya sebagai fasilitator, guru mengevaluasi produk hasil kinerja siswa meliputi outcome yang mampu ditampilkan dari hasil proyek yang dikerjakan ${ }^{[7]}$. Pembelajaran berbasis proyek ini dipandang cocok dengan karakteristik kurikulum KTSP yang menempatkan siswa sebagai pusat pembelajaran dan mata pelajaran fotografi lebih banyak melakukan kegiatan praktikum untuk menghasilkan suatu produk nyata dengan tujuan 
meningkatkan motivasi, kemampuan berpikir tingkat tinggi, memahami materi secara menyeluruh, dan meningkatkan keterampilan siswa.

Project based learning memiliki kelemahan salah satunya yaitu peserta didik yang memiliki kelemahan dalam percobaan dan pengumpulan informasi akan mengalami kesulitan, sehingga untuk mengatasinya maka model pembelajaran ini diterapkan dengan berbantuan media CAI. Dalam pengembangan e-modul yang dirancang dengan Moodle nantinya akan disediakan fitur-fitur yang menunjang aktivitas siswa pada setiap tahap pembelajaran model project based learning. Media CAI pada e-modul yang terdiri dari tutorial, simulasi, dan drill and practice akan di implementasikan pada setiap kegiatan pembelajaran untuk meningkatkan tingkat pemahaman materi siswa.

Berdasarkan penelitian sebelumnya, beberapa hasil yang relevan dengan penelitian e-modul yaitu menyatakan bahwa e-modul berbasis flip book maker mendapatkan penilaian positif dan materi pembelajaran menjadi sangat mudah dipahami oleh siswa, pengoperasian modul tersebut sangat mudah, unsur musik dan animasi dinilai dapat meningkatkan motivasi, minat, dan aktivitas belajar para peserta didik [8]. Modul berbasis project based learning mendapatkan hasil pengembangan layak digunakan sebagai bahan ajar dalam pembelajaran fisika pada pokok alat-alat optik dan membantu mengoptimalkan life skill siswa ${ }^{[9]}$.

Berdasarkan uraian di atas, maka peneliti merasa sangat perlu untuk melakukan penelitian dengan judul "Pengembangan E-Modul Berbantuan Media CAI Pada Mata Pelajaran Fotografi Kelas X Desain Komunikasi Visual Di SMK Negeri 1 Sukasada".

\section{METODE}

Penelitian ini merupakan jenis penelitian dan pengembangan (Research and Development). Metode penelitian dan pengembangan atau dalam bahasa Inggrisnya Research and Development adalah metode penelitian yang digunakan untuk menghasilkan produk tertentu, dan menguji keefektifan produk tersebut. Untuk dapat menghasilkan produk tertentu digunakan penelitian yang bersifat analisis kebutuhan dan untuk menguji keefektifan produk tersebut supaya dapat berfungsi di masyarakat luas, maka diperlukan penelitian untuk menguji keefektifan produk tersebut ${ }^{[6]}$.

Model pengembangan yang digunakan dalam penelitian ini adalah model ADDIE. Model pengembangan ini terdiri dari lima tahap yaitu Analyze (analisis), Design (perancangan), Development (pengembangan), Implementation (implementasi), dan Evaluation (evaluasi). Dalam penelitian ini digunakan instrumen berupa angket untuk mengumpulkan data yang dibutuhkan terkait informasi tentang sumber belajar, karakteristik siswa, uji kevalidan e-modul, serta uji respon guru dan siswa terhadap emodul yang dikembangkan. Teknik pengumpulan data dapat dilihat pada Tabel 1.

Tabel 1 Teknik Pengumpulan Data

\begin{tabular}{|c|c|c|c|}
\hline No. & Jenis Data & Metode & Sumber Data \\
\hline 1 & $\begin{array}{l}\text { Informasi tentang } \\
\text { sumber belajar }\end{array}$ & Angket & Guru Mata Pelajaran Fotografi \\
\hline 2 & Karakteristik pembelajar & Angket & Siswa kelas X DKV SMK Negeri 1 Sukasada \\
\hline 3 & Kevalidan E-modul & Angket & $\begin{array}{l}\text { Ahli Isi Pembelajaran, Ahli Desain } \\
\text { Pembelajaran, dan Ahli Media Pembelajaran }\end{array}$ \\
\hline 4 & Respon e-modul & Angket & $\begin{array}{l}\text { Siswa kelas X DKV dan guru mata pelajaran } \\
\text { Fotografi }\end{array}$ \\
\hline
\end{tabular}

Pada kegiatan observasi guna mendapat informasi sumber belajar dan karakteristik pembelajar, digunakan jenis angket terbuka. Melalui metode angket ini 
peneliti mengetahui masalah yang terjadi ketika pembelajaran berlangsung terkait sumber belajar, materi, media, dan ketertarikan siswa dalam pembelajaran fotografi. Uraian singkat tentang teknis analisis data yang digunakan dalam penelitian ini adalah sebagai berikut.

1. Analisis data kevalidan e-modul

Rumus yang digunakan menghitung persentase masing-masing subyek sebagai berikut ${ }^{[7]}$.

Persentase $=\sum \frac{\text { (Iawaban xbobot tiap pilihand }}{n \times \text { bobot tertinggi }} \times 100 \%$

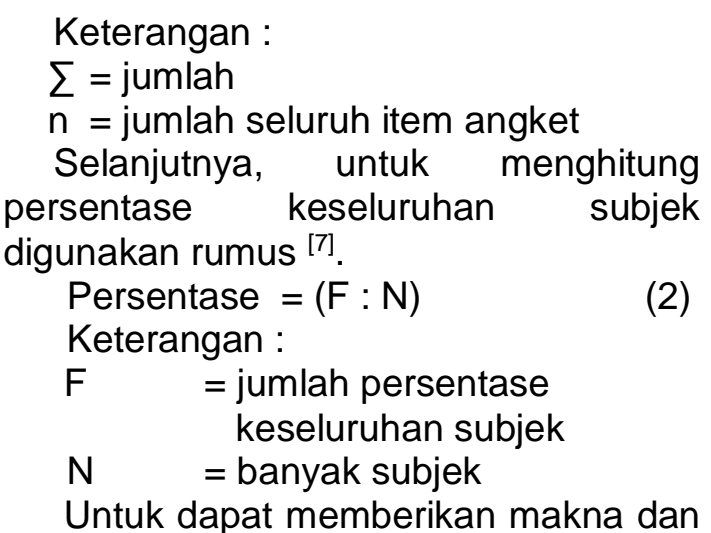

pengambilan keputusan maka digunakan ketetapan terhadap hasil review dan uji coba produk sebagai berikut.

2. Analisis data respon guru dan siswa

Untuk melakukan perhitungan analisis data respon maka didasarkan pada ratarata kelas $(\bar{x})$ dari respon siswa, Mi, SDi. Rata-rata kelas dari skor respon siswa dihitung dengan rumus ${ }^{[2]}$.

$\bar{x}=\frac{\sum x}{N}$

Keterangan:

$\bar{x}=$ Rata - rata kelas untuk skor respon siswa

$\sum x=$ Jumlah skor respon siswa

$\mathrm{N}$ = Banyaknya siswa

Sedangkan untuk mencari mean ideal (Mi) dan standar deviasi ideal (SDi) digunakan rumus sebagai berikut ${ }^{[2]}$ :

$M i=\frac{1}{2}($ skor maksimal + skor terendah $)$

$S D i=\frac{1}{6}$ (skor tertinggi + skor terendah $)$

Rata-rata kelas $(\bar{x})$ dari skor respon kemudian dikategorikan dengan menggunakan pedoman pada Tabel 2 .

Tabel 2 Kriteria Penggolongan Respon ${ }^{[4]}$

\begin{tabular}{cll}
\hline No & \multicolumn{1}{c}{ Interval } & \multicolumn{1}{c}{ Kategori } \\
\hline 1 & $\mathrm{Mi}+1,5 \mathrm{SDi} \leq \bar{x}$ & Sangat Positif \\
2 & $\mathrm{Mi}+0,5 \mathrm{SDi} \leq \bar{x}<\mathrm{Mi}+1,5 \mathrm{SDi}$ & Positif \\
3 & $\mathrm{Mi}-0,5 \mathrm{SDi} \leq \bar{x}<\mathrm{Mi}+0,5 \mathrm{SDi}$ & Kurang Positif \\
4 & $\mathrm{Mi}-1,5 \mathrm{SDi} \leq \bar{x}<\mathrm{Mi}-1,5 \mathrm{SDi}$ & Negatif \\
5 & $\bar{x}<\mathrm{Mi}-1,5 \mathrm{SDi}$ & Sangat Negatif \\
\hline
\end{tabular}

\section{HASIL DAN PEMBAHASAN}

Pengembangan e-modul fotografi memiliki tujuan untuk membantu penambahan sumber belajar, media pembelajaran, dan diharapkan dapat meningkatkan pemahaman materi pelajaran fotografi selama proses belajar mengajar di kelas. Berdasarkan hasil observasi awal yang dilakukan, dapat diketahui bahwa siswa belum memiliki modul yang sesuai dengan standar kompetensi sehingga dalam proses pembelajaran hanya berpedoman pada penyampaian materi dari guru pengajar dan media pembelajaran yang digunakan selama ini belum membantu mengatasi masalah tidak adanya modul ajar. Hal ini berdampak terhadap kurangnya tingkat pemahaman peserta didik dan pembelajaran cenderung berpusat pada guru, berbanding terbalik dengan penerapan kurikulum KTSP yang mengutamakan kegiatan pembelajaran berpusat pada siswa (student center). Akibatnya proses belajar mengajar menjadi kurang efektif dan tidak menarik bagi siswa, sehingga pengembangan e-modul berbasis web yang dikemas dengan berbagai penyajian materi yang lebih konkret, nyata, dan dilengkapi simulasi pendukung pembelajaran sesuai dengan perkembangan teknologi terkini sangat diperlukan. 
Pengembangan e-modul fotografi menggunakan model project based learning (PjBL), dengan tujuan membuat siswa menjadi terdorong lebih aktif dalam proses pembelajaran. Sesuai dengan tahapan pada model pengembangan ADDIE, tahapan pertama yang dilakukan adalah analyze (analisis) meliputi kegiatan analisis mata pelajaran yang terdiri dari: (a) Analisis Tujuan dan Karakteristik Isi Bidang Studi, (b) Menetapkan Indikator dan Isi Pembelajaran, (c) Menetapkan Strategi Pengorganisasian Isi Pembelajaran, (d) Menetapkan Strategi Penyampaian Isi Pembelajaran, (e) Menetapkan Strategi Pengelolaan Pembelajaran. Selanjutnya melakukan analisis ketersediaan sumber belajar dan analisis karakteristik pembelajar.

Tahap kedua adalah design (desain) meliputi penyusunan draft modul dan perancangan e-modul. Tahap ketiga adalah development (pengembangan) yang meliputi kegiatan pengembangan modul, pengembangan e-modul, dan integrasi fitur Moodle pada e-modul. Kegiatan penyusunan modul meliputi pengumpulan bahan/materi pelajaran, pengetikan bahan ajar, dan penyusunan materi sesuai kompetensi yang diharapkan. Kegiatan pengembangan e-modul meliputi pembuatan media pembelajaran berupa tutorial dan simulasi, pengembangan rancangan antarmuka pada aplikasi Moodle berdasarkan rancangan struktur menu (sitemap), dan mengatur hak akses pengguna. Sedangkan kegiatan pengembangan integrasi fitur Moodle pada e-modul meliputi penerapan hasil modul ke dalam aplikasi Moodle hingga menjadi produk akhir berupa e-modul. Pengembangan pada fitur Moodle disesuaikan dengan kerangka modul yang digunakan dan berisikan implementasi dari tahapan project based learning pada emodul.

$\begin{array}{clr}\text { Tahap } & \text { keempat } & \text { adalah } \\ \text { implementation } & \text { (implementasi) } & \text { yang }\end{array}$
dilakukan dengan menguji coba e-modul sesuai dengan peran dan fungsinya dalam proses pembelajaran untuk mengetahui sejauh mana manfaat produk yang dikembangkan. Tahapan uji coba dimulai dari review para ahli, kemudian dilanjutkan dengan uji coba perorangan, kelompok kecil, dan uji lapangan. Uji ahli yang pertama dilakukan adalah uji ahli isi pembelajaran. Setelah selesai melakukan uji ahli isi, kemudian dilanjutkan dengan uji ahli desain dan ahli media pembelajaran.

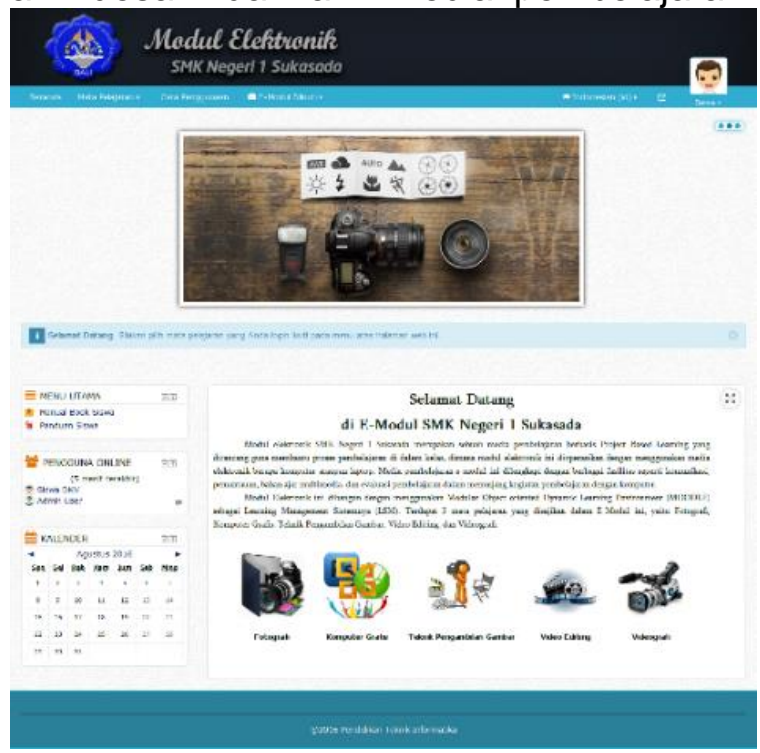

Gambar1. Halaman Utama Pengguna

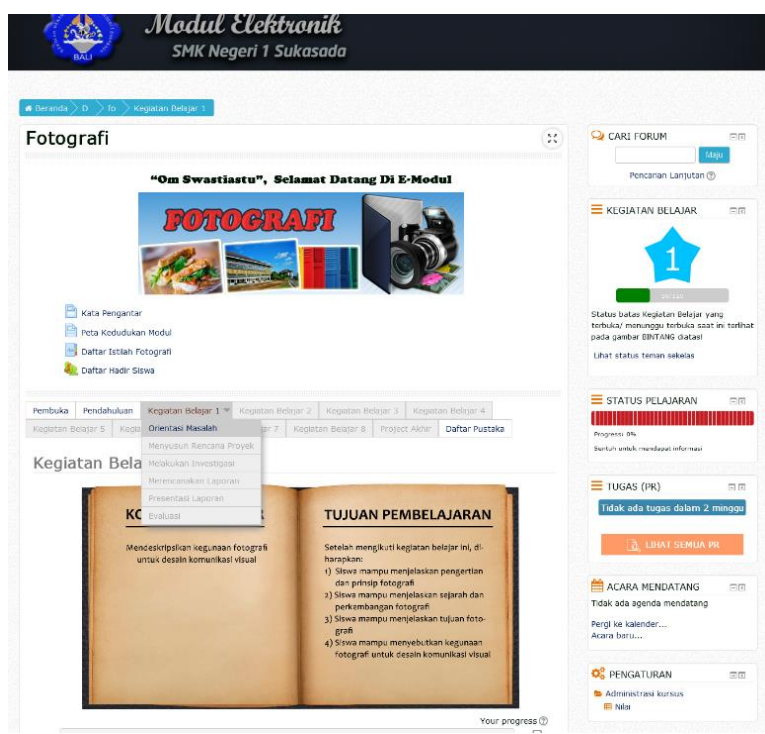

Gambar 2. Halaman Kegiatan Belajar

Hasil penilaian ahli isi berdasarkan angket menunjukkan bahwa tingkat pencapaian dari e-modul adalah "SESUAl" dan layak untuk dilanjutkan. Hal tersebut mengindikasikan bahwa materi pelajaran yang diimplementasikan dalam e-modul sudah relevan untuk digunakan dalam pembelajaran fotografi. Materi pelajaran yang memadukan sajian materi dari 
beberapa sumber buku sebagai referensi pembelajaran dinyatakan valid dan sudah sesuai dengan indikator dan tujuan pembelajaran pada silabus fotografi Desain Komunikasi Visual. Karakteristik materi pelajaran fotografi yang cenderung mengarah praktikum dan penguasaan alat fotografi, pada e-modul sudah dipaparkan dengan bantuan visualisasi melalui gambar dan video sehingga memudahkan pemahaman materi oleh siswa. Beberapa masukan yang menjadi revisi produk emodul dari segi isi pembelajaran seperti melengkapi materi pada kegiatan belajar 4, telah dilakukan revisi dengan menambahkan video pengenalan fitur-fitur kamera digital SLR yang belum ada sebelumnya.

$\begin{array}{ccc}\text { Hasil } & \text { penilaian ahli desain } \\ \text { pembelajaran } & \text { terhadap } & \text { produk }\end{array}$
pengembangan e-modul yang terdiri dari kelayakan isi, penyajian, tahap pembelajaran model project based learning, dan model pembelajaran sudah dinyatakan "SESUAl" dan layak untuk dilanjutkan. Hal tersebut mengindikasikan bahwa penerapan model pembelajaran project based learning dalam e-modul layak untuk digunakan dalam pembelajaran fotografi. Melalui penerapan langkah-langkah model project based learning dalam pembelajaran membuat siswa lebih aktif melalui proyek yang diberikan pada masing-masing kegiatan belajar. Selain itu project based learning memberikan pengalaman kepada peserta didik melalui pembelajaran dan praktik dalam mengorganisasi proyek, dan membuat alokasi waktu dan sumbersumber lain seperti perlengkapan untuk menyelesaikan tugas. Masukan ahli desain seperti penggunaan bahasa dalam modul agar diupayakan memperhatikan karakteristik siswa yang menjadi objek penelitian telah dilakukan melalui pemeriksaan kembali isi e-modul secara keseluruhan agar e-modul valid dari segi desain pembelajaran.

Hasil penilaian ahli media pembelajaran yang terdiri dari penggunaan bahasa dan keterbacaan, grafis, desain tampilan e-modul, efektivitas, dan media yang dikembangkan dalam e-modul fotografi telah dinyatakan "SESUAl" dan layak untuk dilanjutkan. Media pembelajaran dalam e-modul yang disajikan dalam bentuk teks, gambar, animasi, ataupun video disajikan dengan tepat dan jelas, sehingga siswa dengan mudah dapat belajar dan memahami fotografi. Hasil penilaian ahli media mengindikasikan bahwa produk e-modul yang sudah dikembangkan layak untuk digunakan dalam pembelajaran fotografi. Dari evaluasi ahli media, terdapat saran yang diberikan seperti : penambahan plagiarism checker ke dalam e-modul. Revisi telah dilakukan penulis dengan menambahkan plugin turnitin plagiarism pada sistem e-modul, namun fitur ini belum dimanfaatkan karena memerlukan lisensi (berbayar). Sehingga penulis mencari alternatif lain dengan menggunakan plagiarism checker gratis untuk versi program desktop.

Langkah selanjutnya yaitu melakukan implementasi yang meliputi uji perorangan, uji kelompok kecil, uji lapangan, uji respon guru, dan uji respon siswa. Subjek uji perorangan adalah tiga orang siswa kelas $X$ Desain Komunikasi Visual. Dari hasil angket uji coba yang diisi oleh masingmasing siswa, terdapat satu orang siswa memberikan tanggapan sangat baik $(33,33 \%)$, dua orang siswa yang memberikan tanggapan baik $(66,67 \%)$, dan tidak ada siswa yang memberikan tanggapan cukup, kurang, maupun sangat kurang. Rata-rata penilaian siswa adalah $88,33 \%$. Jika dikonversikan ke dalam tabel konversi termasuk dalam kategori baik. Revisi pada tahap uji coba perorangan ini hanya dengan perbaikan kesalahan ketik pada kalimat momen. Penilaian uji coba perorangan memperoleh hasil baik dari kategori tertinggi yaitu sangat baik. Berdasarkan pengamatan langsung dan wawancara dengan guru pengajar fotografi, responden uji coba perorangan ini adalah siswa kelas $X$ yang baru menguasai pengoperasian komputer dasar, sehingga ketika dilakukan uji coba siswa masih perlu beradaptasi dengan penggunaan e-modul dalam pembelajaran. Solusi pada kegiatan uji coba perorangan ini dilakukan peneliti dengan mengarahkan siswa untuk membaca tutorial pengguna yang sudah terdapat pada e-modul dan mengajarkan cara penggunaannya. 
Tabel 3. Rekapitulasi Penilaian Pada Uji Coba Perorangan

\begin{tabular}{lll}
\hline $\begin{array}{l}\text { Konversi tingkat } \\
\text { pencapaian }\end{array}$ & Persentase (\%) & $\begin{array}{l}\text { Jumlah Responden } \\
\text { (orang) }\end{array}$ \\
\hline Sangat Baik & $33,33 \%$ & 1 \\
Baik & $66,67 \%$ & 2 \\
Cukup & $0 \%$ & 0 \\
Kurang & $0 \%$ & 0 \\
Sangat Kurang & $0 \%$ & 0 \\
\hline
\end{tabular}

\section{Uji Coba Perorangan}

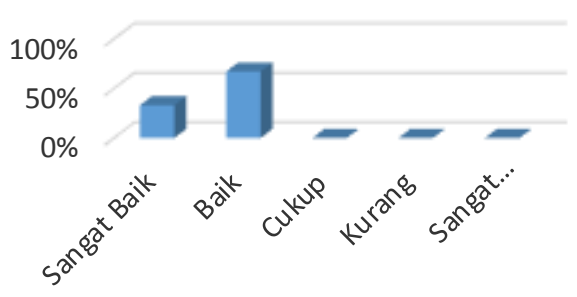

Gambar 3. Grafik Hasil Rekapitulasi Uji Perorangan

Setelah uji perorangan selesai dan direvisi, maka dilanjutkan dengan uji kelompok kecil. Uji kelompok kecil dilakukan oleh dua belas orang siswa kelas $X$ Desain Komunikasi Visual. Dari hasil angket uji coba kelompok kecil yang diisi oleh masing-masing siswa, terdapat empat orang siswa memberikan tanggapan sangat baik $(33,33 \%)$, delapan orang siswa memberikan tanggapan baik $(66,67 \%)$, dan tidak ada siswa yang memberikan tanggapan cukup, kurang, maupun sangat kurang. Rata-rata penilaian dua belas orang siswa adalah $87,75 \%$. Jika dikonversikan ke dalam tabel konversi termasuk dalam kategori baik. Revisi yang sudah dilakukan untuk mengatasi siswa yang belum mengerti pengoperasian e-modul adalah menambahkan video tutorial cara penggunaan e-modul. Pada uji coba kelompok kecil terdapat beberapa hal yang menjadi penyebab siswa belum mengerti pengoperasian e-modul berdasarkan pengamatan di lapangan yaitu siswa belum paham penggunaan komputer dasar dengan baik, selama ini metode pembelajaran yang dilakukan siswa adalah penggunaan modul cetak sehingga ini merupakan pengalaman awal menggunakan pembelajaran berbasis komputer, sehingga membutuhkan penyesuaian dan penjelasan lebih lengkap tentang e-modul. Namun beberapa temuan tersebut sudah dicoba diatasi oleh peneliti dengan mendampingi siswa secara langsung dalam pengoperasian e-modul dan penggunaan video tutorial pengoperasian e-modul.

Tabel 4. Rekapitulasi Penilaian Pada Uji Coba Kelompok Kecil

\begin{tabular}{llll}
\hline $\begin{array}{c}\text { Konversi tingkat } \\
\text { pencapaian }\end{array}$ & \multicolumn{1}{c}{$\begin{array}{c}\text { Persentase } \\
(\%)\end{array}$} & \multicolumn{1}{c}{$\begin{array}{c}\text { Jumlah Responden } \\
\text { (orang) }\end{array}$} \\
\hline Sangat Baik & $33,33 \%$ & 4 & \\
Baik & $66,67 \%$ & 8 \\
Cukup & $0 \%$ & 0 & \\
Kurang & $0 \%$ & 0 \\
Sangat Kurang & $0 \%$ & 0 & \\
\hline
\end{tabular}




\section{Uji Coba Kelompok Kecil}

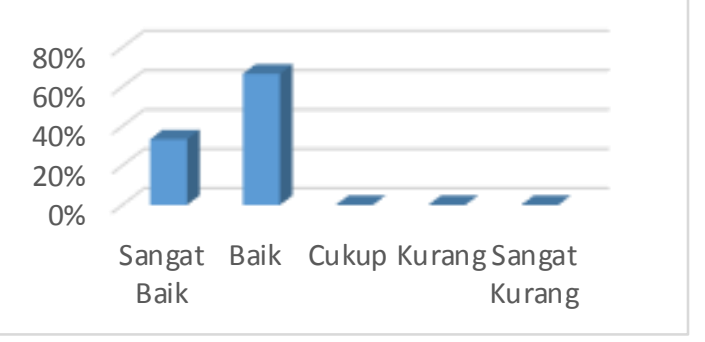

\section{Gambar 4. Grafik Rekapitulasi Uji} Kelompok Kecil

Setelah uji coba kelompok kecil selesai dilanjutkan dengan uji lapangan yang dilakukan oleh sembilan belas orang siswa kelas X Desain Komunikasi Visual di SMK Negeri 1 Sukasada. Dari hasil angket uji coba diperoleh dua belas orang siswa memberikan tanggapan sangat baik $(63,16 \%)$, tujuh orang siswa memberikan tanggapan baik $(36,84 \%)$, dan tidak ada siswa yang memberikan tanggapan cukup, kurang, maupun sangat kurang. Rata-rata penilaian keseluruhan responden uji lapangan adalah 90,11\%. Jika dikonversikan ke dalam tabel konversi tingkat pencapaian termasuk dalam kategori sangat baik dan tidak perlu revisi pada e-modul. Berdasarkan temuan di lapangan, penggunaan e-modul dalam proses kegiatan belajar mengajar di kelas dapat membantu siswa memahami materi lebih cepat dan meningkatkan interaksi antar guru dan siswa. Melalui isi materi yang disajikan dalam bentuk teks, gambar, dan video dalam e-modul siswa lebih mudah memahami materi dan sangat membantu dalam pengerjaan proyek. Keberhasilan model pembelajaran project based learning untuk meningkatkan aktivitas belajar siswa disebabkan oleh penerapan model project based learning yang membantu siswa terlibat secara aktif mengikuti pembelajaran. Model project based learning memberikan kesempatan siswa untuk belajar menyenangkan, sehingga menumbuhkan minat siswa untuk belajar dan mendorong siswa untuk mengembangkan keterampilannya.

Tabel 5. Rekapitulasi Penilaian Pada Uji Coba Lapangan

\begin{tabular}{lcc}
\hline $\begin{array}{c}\text { Konversi tingkat } \\
\text { pencapaian }\end{array}$ & Persentase (\%) & $\begin{array}{c}\text { Jumlah Responden } \\
\text { (orang) }\end{array}$ \\
\hline Sangat Baik & 63,16 & 12 \\
Baik & 36,84 & 7 \\
Cukup & $0 \%$ & 0 \\
Kurang & $0 \%$ & 0 \\
Sangat Kurang & $0 \%$ & 0 \\
\hline
\end{tabular}

\section{Uji Coba Lapangan}

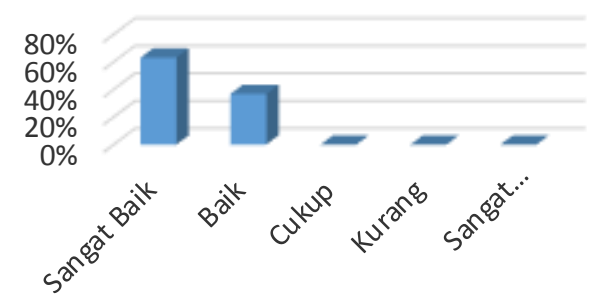

Gambar 5. Grafik Hasil Rekapitulasi Uji Lapangan

Setelah hasil uji lapangan selesai dilakukan, selanjutnya dilakukan pengambilan respon guru terhadap pengembangan e-modul pada mata pelajaran fotografi. Uji respon guru dilakukan oleh satu orang responden yaitu Bapak Wayan Mudita, S.Pd dan memperoleh rata-rata sebesar 47 , jika dikonversikan ke dalam tabel kriteria penggolongan respon maka hasilnya termasuk dalam kategori sangat positif. Proses uji selanjutnya dilakukan dengan pengambilan respon siswa. Subjek uji coba respon siswa adalah terdiri dari 19 orang siswa kelas $X$ Desain Komunikasi Visual yang telah belajar menggunakan e-modul. Hasil angket respon siswa terhadap pengembangan e-modul fotografi 
memperoleh rata-rata sebesar 67,79, jika dikonversikan ke dalam tabel kriteria penggolongan respon maka hasilnya termasuk dalam kategori sangat positif. Berdasarkan hasil respon guru dan siswa dapat dikategorikan membantu siswa dalam memahami mata pelajaran fotografi dan berhasil mengatasi permasalahan tidak adanya modul ajar.

Hasil penelitian e-modul berbantuan media CAI pada mata pelajaran fotografi ini sejalan dengan penelitian Suarsana dan Mahayukti (2013) tentang Pengembangan E-modul Berorientasi Pemecahan Masalah yaitu sama-sama memperoleh penilaian layak dan mendapat respon sangat positif. E-modul berorientasi pemecahan masalah dan e-modul fotografi yang dikembangkan, melewati serangkaian validasi ahli dan uji coba produk untuk menghasilkan produk yang berkualitas. Dalam implementasinya pengembangan e-modul Suarsana dan Mahayukti (2013) dan penelitian ini dilengkapi dengan forum diskusi dan simulasi interaktif untuk mendorong subjek penelitian belajar untuk kritis dan selektif, hanya saja yang membedakan pada pengembangan e-modul fotografi ini bersifat offline menggunakan jaringan Local Area Network (LAN). Dari segi desain pengembangan Moodle, keterbacaan, dan keefektifan produk, e-learning dengan Moodle yang dikembangkan Putra, Suwatra, \& Suartama (2015) mampu meningkatkan hasil belajar siswa. Dalam elearning berbasis Moodle, kegiatan pembelajaran disusun secara sistematis dilengkapi dengan forum diskusi, materi beserta contoh-contoh berupa video dan gambar yang menarik, dan penugasan/quis agar siswa lebih termotivasi untuk belajar. Hal ini juga diterapkan pada e-modul fotografi yang dikembangkan dengan Moodle, desain pembelajaran disajikan semenarik mungkin, fitur pembelajaran disajikan dengan jelas dan lengkap, penggunaan huruf dan media disajikan dengan rapi dan mudah dipahami.

Berdasarkan pembahasan di atas, penilaian-penilaian yang dilakukan oleh ahli isi, ahli desain pembelajaran, ahli media, uji coba perorangan, uji coba kelompok kecil, uji lapangan, maupun hasil respon guru dan siswa termasuk dalam kategori baik dan mendapat respon positif. Berdasarkan penilaian tersebut, secara garis besar pengembangan e-modul berbantuan media CAl pada mata pelajaran fotografi telah menunjukkan adanya keberhasilan dan layak digunakan sebagai sumber belajar untuk siswa kelas $X$ Desain Komunikasi Visual di SMK Negeri 1 Sukasada. Hal ini didukung pula dengan beberapa pernyataan siswa yaitu keberadaan emodul fotografi sangat membantu dalam proses pembelajaran, e-modul membuat siswa lebih antusias dalam belajar fotografi, maupun memudahkan siswa memahami materi lebih cepat dan sangat efektif dalam pelajaran. Melalui penerapan e-modul fotografi ini diharapkan dapat membantu guru selama proses pembelajaran dan masalah selama proses pembelajaran terkait sumber belajar mampu teratasi, intensitas belajar siswa meningkat, dan membantu siswa menjadi lebih aktif dalam proses belajar mengajar secara mandiri maupun berkelompok.

\section{SIMPULAN DAN SARAN}

Berdasarkan hasil penelitian dan pembahasan, maka penulis dapat menarik kesimpulan sebagai berikut. (1) Hasil rancangan dan implementasi pengembangan e-modul berbantuan media CAI pada mata pelajaran fotografi kelas $X$ Desain Komunikasi Visual di SMK Negeri 1 Sukasada menggunakan tahapan model project based learning sudah dinyatakan berhasil diterapkan. Hal ini dapat dilihat dari rata-rata persentase berdasarkan hasil pengujian yang telah dilakukan. Secara umum siswa terlihat antusias dan lebih aktif selama proses pembelajaran berlangsung. (2) Respon guru terhadap pengembangan e-modul berbantuan media CAI pada mata pelajaran fotografi kelas $X$ Desain Komunikasi Visual di SMK Negeri 1 Sukasada didapatkan rata-rata sebesar 47. Jika dikonversikan ke dalam tabel kriteria penggolongan respon maka hasilnya termasuk dalam kategori sangat positif. Sedangkan untuk respon siswa terhadap pengembangan e-modul fotografi memperoleh rata-rata sebesar 67,79. Jika dikonversikan ke dalam tabel kriteria penggolongan respon maka hasilnya termasuk dalam kategori sangat positif. 
Berdasarkan pengamatan penulis, terdapat beberapa hal yang dapat dijadikan bahan pertimbangan untuk ditindak lanjuti. (1) Pengujian produk e-modul berbantuan media CAI pada mata pelajaran fotografi kelas X Desain Komunikasi Visual di SMK Negeri 1 Sukasada hanya terdiri dari uji ahli isi pembelajaran, ahli desain pembelajaran, ahli media, dan uji coba terbatas, untuk selanjutnya perlu dilakukan pengujian untuk menilai usability dan user experience dari sistem e-modul fotografi. (2) Produk emodul berbantuan media CAI pada mata pelajaran fotografi kelas $X$ Desain Komunikasi Visual di SMK Negeri 1 Sukasada yang dikembangkan belum sampai pada tahap pengukuran hasil belajar siswa. Oleh karena itu, perlu diadakan pengkajian lebih lanjut mengenai efektivitas penggunaan e-modul berkaitan dengan pengukuran hasil belajar siswa menggunakan e-modul ini melalui penelitian eksperimen. (3) Bagi pengembang e-modul selanjutnya agar dapat mengatur e-modul lebih user friendly atau mudah digunakan bagi pengguna yang masih belum terbiasa dengan pembelajaran berbasis komputer. Selain itu, dapat mengatur konsistensi penggunaan bahasa sesuai pilihan pada emodul dan meningkatkan fitur pembelajaran berupa games pembelajaran atau bentuk lainnya agar siswa tidak merasa bosan ketika belajar menggunakan e-modul.

\section{DAFTAR PUSTAKA}

Adnyana, I P. (2014). Pengembangan Modul Ajar Melakukan Instalasi Perangkat Jaringan Lokal Untuk Siswa Kelas XI Program Keahlian Teknik Komputer dan Jaringan (TKJ) Di Smk Negeri 3 Tabanan. Kumpulan Artikel Mahasiswa Pendidikan Teknik Informatika (KARMAPATI), 39-45.

Nurkancana, W., \& Sunartana, P. (1992). Evaluasi Hasil Belajar. Surabaya: Usaha Nasional.

Putra, P. G., Suwatra, I W., \& Suartama, I K. (2015). Pengembangan E-Learning erbasis Moodle Pada Mata Pelajaran IPS Kelas VIII Di SMPN 1 Selemadeg. e-Journal Edutech Universitas Pendidikan Ganesha.
Santyasa, I W. (2006). Pembelajaran Inovatif: Model kolaboratif, basis proyek, dan orientasi NOS. Makalah. Disajikan dalam seminar di Sekolah Menengah Atas (SMA) Negeri 2 Semarapura, 27 Desember 2006, di Semarapura.

Suarsana, I M., \& Mahayukti, G. A. (2013). Pengembangan E-modul Berorientasi Pemecahan Masalah untuk Meningkatkan Keterampilan Berpikir Kritis Mahasiswa. Jurnal Nasional Pendidikan Teknik Informatika (JANAPATI), 193-200.

Sugiyono. (2012). Metode Penelitian Kuantitatif, Kualitatif dan $R \& D$. Bandung: Alfabeta.

Tegeh, I M., \& Kirna, I M. (2010). Metode Penelitian Pengembangan Pendidikan. Singaraja: Universitas Pendidikan Ganesha.

Wijayanto, \& Zuhri, M. S. (2014). Pengembangan E-modul Berbasis Flip Book Maker Dengan Model Project Based Learning Untuk Mengembangkan Kemampuan Pemecahan Masalah Matematika. Prosiding Mathematics and Science Forum 2014, 625 - 628.

Yulianti, S., Fatmaryanti, S. D., \& Ngazizah, N. (2014). Pengembangan Modul Berbasis Project Based Learning untuk Mengoptimalkan Life Skills pada Siswa Kelas X SMA N 1 Petanahan Tahun Pelajaran 2013/2014. RADIASI - Pendidikan Fisika, 40 - 45. 